this lighter water is raised above the level of its own basin it will naturally flow off in the direction in which it meets the least resistance."

To conclude, I argue that while the wind undoubtedly influences the direction taken by ocean currents, difference of gravity, and not wind, is the principal promoter of them. The perfect agreement between the two systems of ocean and atmospheric currents alluded to in the Quarterly is, in my opinion, to be accounted for from similar causes producing similar effects.

How can the winds influence ocean currents running for thotsands of miles below the surface, or how can they influence the direction of the lower strata of surface currents ranging say from 50 to 600 feet in depth, the latter being the depth of the Gulf Stream off Hatteras?

DigBY MURRAY

$$
\text { January } 25
$$

Mr. Digby Murray (vol. xv. p. 294), in common with a great number of meteorologists, maintains that the surface-trades have come, as upper-currents, from the Arctic and Antarctic regions, and that the prevailing westerlies of the extra-tropical regions have come, as upper-currents, from the equator, without intermingling their volume in the district of the tropical calms.

He argues that this must be the case, because the surfacetrades on the interior borders of the tropical calns differ from the westerlies on the exterior borders in their degrees of electri. city, and of saturation, and in other particulars.

I regard this argument as incontestably sound, provided always that no objection can be taken to the assumption on which it rests. That assumption may thus, as I conceive, be fairly stated : "Atmospheric currents differing greatly in character must have travelled from widely distant regions of the globe."

This premise is plausible, and the objection which $I$ have to offer to it rests upon a fact which is, unfortunately, obscure, and which has received very little attention.

Some light is frequently thrown on the more general and permanent atmospheric circulation of our globe by the analogy of the local and temporary systems of circulation which we examine in our own latitudes. Now the most local currents often differ very remarkably in character according to the direction in which they move : e.g., the easterly winds felt on the south border of a small anticyclone, if pursued for a very limited distance into the district in which they begin to travel from the south, are often found to have undergone complete change in their electrical conditions, in the aspect of the clouds which they carry, in their humidity, in their amount of ozone, and finally even in their effects on the animal frame. Still more extraordinary are the alterations often noticeable in the different segments of very local cyclonic circulations. In the case of the smallest secondary depressions I have, very frequently indeed, been struck by the wonderful alteration in the several atmospheric conditions, and especially by the reversal of the electrical conditions, which immediately attends the springing up of a northerly breeze, when the barometric minimum has passed to the east. This breeze, in many of these examples, occupies a very short as well as very narrow belt, and is only of a few hours' duration. What is more important, it is usually of very limited depth. The synchronous upper-current observations at which $I$ have been for some years at work, prove that in many instances of very local depressions the cirrus travels from southerly or westerly points for many hundred miles on all sides of the small depression, as well as immediately over it, in some cases very slightly affected, in others absolutely unaffected, by the limited circulation at the earth's surface.

Until therefore it can be shown (in contradiction to what is indicated by this fact) that our most local currents, if differing in character, have travelled to us at a great elevation from very high and very low latitudes respectively, I cannot hitherto regard Mr. Digby Murray's reasoning as furnishing an "absolute proof "of the soundness of his position.

From Mr. Murphy's criticisms on my former argument I do not retire, as Mr. Digby Murray may possibly complain that I have done from my discussion with himself, behind a veil of cirrus, after the convenient fashion of the Homeric heroes. But as I have already stated, my agreement with his view that "the imperfection of the Arctic as compared with the Antarctic depression is due to the amount of land in the northern hemisphere" (though differing from him as to the nature of the relation between the cause and the effect), it is perhaps hardly necessary for me to say that from his proposition in NATURE (vol. xy. p. 3I2) I am bound to dissent. I do not think that on Mr. Murphy's hypothetical globe, possessed of an atmosphere con. taining no aqueous vapour, the currents would " act as in our actual atmosphere," or in a manner at all analogous to that which he describes. On this point I am afraid we must agree to diffe $x$ for the present.

February 7

W. Clement Ley

HAVE the auroric iights been studied in regard to their rela. tions with changes in the weather? From casual observations made during the last twenty years it would appear that there are at least two distinct kinds of light so classed. One is brilliant and transparent, of a white, yellowish, bluish, or yellowish-red colour: while the other is semi-opaque and of a bloody red colour. The latter generally seems to be considered in Ireland a forerunner of bad weather, or, to quote a Connemara shepherd, "Them bloody lights are bad." The first kind generally appear as intermittent pencils of light, that suddenly appear and suddenly disappear. Usualiy they proceed or radiate from some place near the north of the horizon; but $I$ have often seen them break from a point in the heavens, this point not being stationary but jumping about within certain limits. The brilliant aurora of 5 eptember, 1870 , was one of the latter class, except that the centre of dispersion was not a point, but an irregular figure, sometimes with three sides, but changing to four and five-sided. It began as rays near the north horizon and proceeded up into the heavens in a south-south-east direction. Sometimes, however, these lights occur as suddenly flashing clouds of light, like those of July 16 last, which were of a white colour ; but at other times I have seen them of blue and reddish yellow. If this class of lights are watched into daylight they appear somewhat like faint ray; of a rising sun. One morning while travelling in West Galway, in the twilight, they were very brilliant, and quite frightened the driver of the car, who thought the sun was going to rise to the north instead of at the east.

The second, or bloody-red light, usually occurs in clouds floating in one direction un into the heavens, but often depressed over a portion of the sky. I have never seen them coming fron the eastward, and only on a few occasions from the southward, they generally proceeding from the west, north-west, or north. If both kinds of light occur at the same time, the second, while passing over the first, dim them. If the second class are watched into daylight they appear as dirty misty clouds that suddenly form and disappear without your being able to say where they cams from or where they went to, or as a queer hazy mist over a portion of the sky that suddenly appears and disappears, or as misty rays proceeding from a point in the horizon. Generally when these clouds occur there is a bank of black clouds to the west ward.

This season has been very prolific in auroric light, as there have been few nights since the rst of October last in which they did not appear, sometimes, however, very faint. Generally they were lights of the second class, but on a few occasions there were a few rays of the first associated with them; on wet nights they made the rain-ciouds or mist of a reddish purplish colour; tints of which could be seen in some of the excessively dark nights we bad in November. On many occasions they were late in the night, being very common and hrilliant during the "dark days" of December a few hours before dawn (about five o'clock). I have watched them carefully this season to see if we had a chance of fine weather, but each time we had a fine clear day they appeared also and the weather broke again. Last week I cnly saw white lights of the first class, very faint on two nights, but the weather has not cleared yet. It has, however, become seasonable, as we have had showers of sleet and snow, while previously it was like spring weather, the trees all budding out, innumerable birds singing morning and evening, and flies and wasps flying about.

Ovoca, January 27

\section{On the Sense of Hearing in Birds}

THE sense of hearing is doubtless of much assistance in discovering the food of such birds as the scansores-to wit, woodpeckers, creepers, wrynecks and the like, which feed on insects.

On one occasion, in a Canadian forest, whilst seated close to a rotting pine trunk, I heard distinct scratchings in the interior, as if mice were nibbling the wood, and on splitting open the trunk, numerous large white larvæ of Hylesinida "woodworms" were found busily employed in making their tunnellings throughout the soft substance of the decayed wood. 